\title{
Apology Subverted: The Commodification of
}

\section{Apology}

\section{Lee Taft ${ }^{\dagger}$}

We are living in a time in which extraordinary, public acts of contrition have become commonplace, so frequent that one pundit describes the atmosphere that pervades our culture as "apology mania." ' As citizens of the United States we have been witnesses to our President's evolving apology in the Monica Lewinsky scandal, a tawdry affair that led to his impeachment in the House of Representatives. The public sphere overflows with discourse about President Clinton's apologies; his first attempt at expressed contrition was viewed as woefully inadequate and his later attempts condemned by many as insincere and politically driven. What a literature search reveals as a topic previously rarely considered has now become a national conversation. Against this historic backdrop, $I$ join the conversation. Here I examine apology and, more particularly, the role of apology in the context of civil mediation.

Apology is not a stranger to the law. In fact, the role of apology has been discussed in a growing body of case law, ${ }^{2}$ and there are numerous legal articles addressing its role in litigation, particularly in the context of

$\doteqdot$ Acting Assistant Dean for Student Life, Harvard Divinity School. I wish to acknowledge the valuable guidance and encouragement of Professor Martha Minow. Harvard Law School: Dean Clarissa Atkinson, Harvard Divinity School; and Professor Ellen S. Pryor, Southem Methodist University School of Law. I am also grateful to the editors of The Yale Law Joumal for their insightful comments and superb editing, and to Gloria Korsman of the Andover-Harvard Theological Library for her research advice and assistance. Finally. I thank Kyle Lunn, my life partner, for allowing me to share a piece of his history in this Essay and for his enthusiasm and support of this project. 11.

1. Barbara Amiel, Saying Sorry Is Fine, but Only to a Point, MACLEAN'S, May 25, 1998, at

2. See, e.g., Groppi v. Leslie, 404 U.S. 496, 506 n.11 (1972) (finding an apology to be a mitigating factor in the assessment of penalties for contempt); Johnson v. Smith. $890 \mathrm{~F}$. Supp. 726, 729 n.6 (N.D. III. 1995) (viewing an apology as a mitigating factor in the assessment of punitive damages); Phinney v. Vinson, 605 A.2d 849, 850 (Vt. 1992) (finding the defendant doctor's apology to be admissible as an admission against interest but insufficient in itself to establish breach of standard of care). For a survey of such cases, see Peler H. Rehm \& Denise R. Beatty, Legal Consequences of Apologizing, 1996 J. DISP. RESOL. 115, 119-28. 
alternative dispute resolution. ${ }^{3}$ Indeed, since the time I completed the original draft of this Essay, two more articles on the topic of apology have appeared. ${ }^{4}$ Many commentators focus on apology in utilitarian terms and promote it as a litigation resource. ${ }^{5}$ What is missing in the literature is deeper reflection on apology as a moral activity. In this Essay, I examine the moral dimension of apology. I argue that when apology is cast into the legal arena, its fundamental moral character is dramatically, if not irrevocably, altered.

My interest in this topic stems from my experience as a civil trial lawyer, a role I filled for more than twenty years before coming to Harvard Divinity School, first as a student and now as a dean. As an injury specialist, I represented people who were victims of the negligent and wanton acts of others, people for whom restoration was limited to monetary compensation and, less frequently, injunctive relief. Over the years, 1 became convinced that something was missing, an essential element the absence of which disrupted my clients' healing. The payment of large verdicts or settlement monies failed to heal the deep wounds of many clients; they continued to suffer and express lingering feelings of anger and resentment. I began to think that the missing, necessary piece for healing was an apology from the offender. I thought that this could, and should, occur as part of the litigation process.

I made this observation firsthand in the early 1980 s when I represented a young widow in a medical negligence case. Her husband had been seriously injured, and the medical team in charge of his care failed to discern the extent of the injuries he had sustained. He died a slow and agonizing death. She was left with small children, few financial resources, and deep feelings of resentment against the doctors in charge of her husband's care. The case was eventually settled, and because there were minor children involved, a hearing was held to apportion the settlement

3. See, e.g., Jonathan R. Cohen, Advising Clients to Apologize, 72 S. CaL. L. REV. 1009 (1999); Stephen B. Goldberg et al., Saying You're Sorry, 3 NEGOTIATION J. 221 (1987); John O. Haley, The Implications of Apology, 20 L. \& SOC'Y REV. 499 (1986); Aviva Orenstcin, Apology Excepted: Incorporating a Feminist Analysis into Evidence Policy Where You Would Least Expect It, 28 Sw. U. L. REV. 221 (1999); Rehm \& Beatty, supra note 2; Hiroshi Wagatsuma \& Arthur Rosett, The Implications of Apology: Law and Culture in Japan and the United States, 20 L. \& SoC'Y REV. 461 (1986); Deborah L. Levi, Note, The Role of Apology in Mediation, 72 N.Y.U. L. REV. 1165, 1183 (1997); Marshall H. Tanick \& Teresa J. Ayling, Alternative Dispute Resolution by Apology: Settlement by Saying "I'm Sorry," HENNEPIN LAW., July-Aug. 1996, at 22.

4. See Cohen, supra note 3; Orenstein, supra note 3.

5. See, e.g., Cohen, supra note 3, at 1013 (arguing in favor of increased utilization of apology); Orenstein, supra note 3, at 223 (proposing an exception to existing evidentiary rules admitting apology as hearsay exception); Rehm \& Beatty, supra note 2 (arguing in favor of statutorily constructed safe harbors for apology); Tanick \& Ayling, supra note 3 (arguing for strategic use of apology in mediation); see also STEPHEN B. GOLDBERG ET AL., DISPUTE RESOLUTION 159-62 (3d ed. 1999) (discussing the potential for apology to further mediation efforts). 
proceeds between the widow and the children. As we left the courthouse after the hearing, she began to rage. I thought she was disappointed in the apportionment ordered by the court or that she regretted settling rather than trying the case. But she denied that either of these feelings was the source of her hostility. She was angry that none of the doctors had ever said he was sorry that his conduct had contributed to her husband's death. She experienced this omission as another injury, moral harm added to professional malpractice. She said that if the doctors had apologized, she would have felt more able "to heal."

What healing means in a legal arena has not been clearly established. In medicine, "to heal" is equated with "to cure." In tort litigation, the area of law from which this Essay is drawn, the law and lawyers tend to equate "to heal" with "to compensate," an equation that overlooks the idea noted by legal scholar Margaret Radin that compensation is a "contested concept." 6 Radin distinguishes between commodified concepts of compensation, "in which harm to persons can be equated with a dollar value," and noncommodified concepts, "in which harm cannot be equated with dollars." " This distinction is helpful because it shows that while commodified concepts of compensation may provide financial redress, such concepts do not necessarily restore moral balance. ${ }^{8} 1$ suggest that it is this restoration of moral balance that lawyers should intend when they speak of healing.

This means that healing must be understood in a nuanced way when considered in a legal context. That is, while a legal client may be physically injured, he may also be spiritually and psychologically broken. A medical patient who experiences healing may "feel healed" because of the cure received, whereas a legal client, like the widow in my illustration, may not necessarily need or experience healing in a physical sense. Healing for clients may have a more pronounced moral dimension, a process that can be facilitated relationally by apology. Apology leads to healing because through apologetic discourse there is a restoration of moral balance-more specifically, a restoration of an equality of regard. ${ }^{9}$ Understood this way,

6. Margaret Jane Radin, Compensation and Commensurability, 43 DUKE LJ. 56, 56 (1993).

7. Id.

8. See id. at 60-62.

9. The offender demonstrates regard in his willingness to apologize. and the offended reflects regard when he chooses to forgive. In law this is a process that would often occur between strangers, so I do not envision that the restoration of regard would necessarily lead to a close interpersonal relationship. Rather, I envision a process in which the offender and the offended would each see and embrace the other's humanity and would recognize that each occupies a place in the wider circle we call life. The process I envision is similar to that described by Desmond Tutu in his explanation of the African word Ubuntu:

[Ubuntu] speaks about the essence of being human: that my humanity is caught up in your humanity because we say a person is a person through other persons .... [W]e set great store by communal peace and harmony. Anything that subverts this harmony is 
apology is valuable because it offers the offender a vehicle for expressing repentance and the offended an opportunity to forgive. Apology, then, is potentially healing for both the offended and the offender.

I argue in this Essay that the performance of apology is a complicated and courageous act, one rich in moral meaning when the apology is authentically expressed. I argue, too, that in its authentic expression apology can facilitate forgiveness and the kind of healing my client desired, the kind of healing I thought should and could occur as part of the litigation process. Yet it is precisely this extraordinary value of apology that leaves me less certain of its proper place in the legal arena today. In an exchange process, apology moves from the realm of moral action into the market sphere. Questions arise: What if an offended client is philosophically tied to a belief structure that insists on the expression of remorse as a condition precedent to forgiveness? Does that not lead to a dangerous dependence on the wrongdoer? In that scenario, does the performance of apology attain value without regard to its sincerity? Are proponents of apology systemically encouraging inauthentic expressions of remorse?

The purpose of this Essay then is to explore the healing possibilities of apology in law, particularly in the context of civil mediation. I show that apology can lead to the kind of healing possibilities that I originally imagined-when the moral dimension is understood and protected. I also show that while there are some in the legal arena who respect apology as part of a moral dialectic, many see apology simply as a strategic device to expedite the resolution of a dispute. I argue against such an instrumental view of apology, one that would protect the offender from the legal consequences attached to it. My thesis is that the use in civil mediation of such a "protected" apology subverts a moral process. This strategic use of apology may not be necessarily unethical within the narrow confines of professional responsibility, yet, as I argue here, the subversion of an otherwise moral process is unethical in the wider realm of human relations.

In order to establish this, I first address some preliminary issues. What is an apology? What are the elements of an apology? How is apology a moral act? Are there cultural difficulties that inhibit apology? And are these exacerbated in the legal arena? For answers to these questions I turn to the literature available, primarily writings in the disciplines of philosophy, psychology, religion, and sociology. I then turn to a more focused discussion of the role of apology in law, identifying some of the impediments to the moral efficacy of apology in legal, civil-mediated proceedings. I show how the law itself provides a safeguard for the moral

injurious, not just to the community, but to all of us, and therefore forgiveness is an absolute necessity for continued human existence.

Archbishop Desmond Tutu, Without Forgiveness There Is No Future, Foreword to EXPLORING FORGIVENESS at xiii, xiii (Robert D. Enright \& Joanna North eds., 1998). 
integrity of apology and conclude with suggestions for how lawyers and mediators can themselves facilitate apologetic discourse in ways that protect the morality of apology.

\section{APOLOGY DEFINED}

The characteristic way for human beings to express repentance or sorrow is through apology. Nicholas Tavuchis, a sociologist who has written a detailed text on the subject of apology and reconciliation, believes that " $[w]$ hatever else is said or conveyed, an apology must express sorrow." 10 Of course, "sorrow" is subject to a variety of meanings," but in the context of apology, sorrow is equated with feelings of remorse, shame, and repentance. This understanding leads Tavuchis to separate the essential requirements for apology into two critical ingredients: "[T]he offender has to be sorry and has to say so." ${ }^{12}$ According to Tavuchis, the fundamental pattern for the expression of remorse is dyadic, an interaction between the offender and offended. ${ }^{13}$ That is, the "exclusive, ultimate, and ineluctable focus" in an apologetic discourse is on the interaction between the offender and offended, entities that Tavuchis sees as "primordial social categories." ${ }^{14}$

The idea that there exists an "apologetic discourse" suggests a further important understanding regarding the dynamics of apology: that the offender's expression of sorrow is a performative utterance. ${ }^{15}$ The sorrow and regret that the offender has experienced internally is converted by speech from "a private condition into public communion." 16 No longer is

10. NichOLAS TAVUCHIS, MEA CULPA 36 (1991).

11. For example, the phrase "I'm sorry" can be interpreted as an expression of sympathy as well as an expression of remorse. See Rehm \& Beatty, supra note 2. at 117.

12. TAvUCHIS, supra note 10 , at 36 .

13. See id. at 46.

14. Id. As I argue later, this idea of the essential aspect of the categories of the offender and the offended becomes especially significant in the context of civil litigation, where medialors and lawyers frequently forget this dynamic. See infra Part V.

15. The classic treatment of performative utterances is in J.L. Austin's William James Lectures at Harvard University in 1955, which are collected in J.L. AUSTIN, HOW TO DO THINGS WITH WORDS (J.O. Urmson \& Marina Sbisà eds., 1975). In those lectures, Austin seeks to challenge the philosophical assumption "that to say something ... is simply to stase something." Id. at 12. To do this Austin contrasts performative utterances against constative utterances. See id. at 148. A constative utterance is one which can be judged true or false, like "the cat is on the mat." Id. at 146. In other cases, Austin shows that "to say something is to do something, or in saying something we do something, and even by saying something we do something." Id. at 94 . Austin calls these utterances "performatives." Id. at 6. A familiar example of a periormative utterance is the utterance "I do" when uttered by the principals in the course of a marriage ceremony. See id. at 5 . Austin likewise describes "I apologize" to be a paradigmatic performative utterance. See id. at 79,146. In this Essay, I rely on Austin's definition and then examine the moral dimension of what is said and done through the utterance of the performatives. "I apologize" or "I am sorry."

16. TAVUCHIS, supra note 10 , at 64 . 
the offender simply wrestling with internalized humiliation and shame; now the offender chooses to give voice to these feelings, to allow a public hearing of the inner conversation. This public expression of repentance constitutes apology as a performative utterance. ${ }^{17}$ And as a speech act, an apology requires some recognizable steps to make it effective.

To create the foundation for an effective apology the offender must first take time-before initiating the communication with the offended party-to "name" the offense, that is, to become clear about the norm that has been violated and about what it is that calls the offender to apologize. During this time, the offender is engaged in an internal process in which he comes to terms with his error, names it, and identifies himself with the action. In this process, the offender moves to a willingness to admit his wrong and to express remorse for the result of his act. The offender has heard the call to repent and has prepared himself to respond. Once the commitment to respond is sealed, then comes the apology itself.

At a minimum, sociologists and psychologists agree that an apology must have as its centerpiece "an expression of sorrow and regret." 18 That is, the primary information to be conveyed in the performance of apology is sorrow, regret, and remorse. ${ }^{19}$ This is accomplished, according to Tavuchis, by a precise formula in which the offender acknowledges through speech the legitimacy of the violated rule, admits fault for its violation, and expresses genuine remorse and regret for the harm caused by his violation. ${ }^{20}$ Others suggest that at this stage there should also be offers of reparation or promises to reform. ${ }^{21}$ Tavuchis rejects these suggestions, maintaining the idea that an expression of "I'm sorry" necessarily includes such offers and promises. The remorse and regret conveyed by the words "I'm sorry" imply a willingness to change, a promise of forbearance, and an implicit agreement to accept all the consequences, social, legal, and otherwise, that flow from having committed the wrongful act. Tavuchis worries that to elaborate the basic formula of apologetic discourse by explicit expression of these implicit ramifications will disrupt the essential message of the apology. In short, for Tavuchis there is value in simplicity, value that is lost if the basic formula he outlines is complicated by explanations and offers of reparation. Tavuchis's point seems well-taken, especially when we consider how easy it is for an apology to fail.

17. See AUSTIN, supra note 15, at 79; see also JORAM GRAF HABER. FORGIVEnESS 100 (1991).

18. Tavuchis, supra note 10, at 23; see also Steven J. Scher \& John M. Darley. How Effective Are the Things People Say To Apologize? Effects of the Realization of the Apology Speech Act, 26 J. PSYCHOLINGUISTIC RES. 127, 130 (1997).

19. See Scher \& Darley, supra note 18, at 130.

20. See TAVUCHIS, supra note 10 , at 3 .

21. See Orenstein, supra note 3, at 239; Scher \& Darley, supra note 18, at 138; Wagatsuma \& Rosett, supra note 3, at 469-70. 
Psychiatrist Aaron Lazare paints a detailed portrait of such failure, which he calls the "botched apology." ${ }^{22}$ This is the apology that not only fails to communicate effectively the offender's repentance, remorse, and regret but creates further harm that can strain relationships or fuel bitter vengeance. ${ }^{23}$ One example, known to most of us, witnessed by many of us, is the failed apology of President Richard Nixon:

I regret deeply any injuries that may have been done in the course of events that have led to this decision [to resign]. I would say only that if some of my judgments were wrong, and some were wrong, they were made in what I believed at the time to be in the best interest of the nation. ${ }^{24}$

What made this a "botched" apology? Nixon failed to acknowledge his specific offense, and he failed to identify the norm broken. Further, he glossed over his wrong by asserting that it was for a greater good. ${ }^{25}$ Senator Robert Packwood's failed apology eclipsed even Nixon's. After being accused of sexually harassing at least a dozen women, Packwood said only, "I'm apologizing for the conduct that it was alleged that I did." ${ }^{26}$

Lazare suggests that apologies like these fail for psychologically foreseeable and predictable reasons. The most common explanation for a failed apology is the offender's pride, which acts as a wall between the offensive act and the feeling of shame for having violated social norms. ${ }^{27}$ As Lazare says, " $[T]$ o apologize, you have to acknowledge that you made a mistake." ${ }^{28}$ This admission collides with values that many take pride in upholding, ethical values like competency and honesty. Who wants to be subjected to public exposure for failing to act competently or honestly? Aversion to such exposure is why apologies are so often expressed in language like "I am sorry you are hurt" rather than in unequivocal terms like "What I did was wrong and I see that my wrong actions hurt you. I am sorry for the injury I have inflicted." It is the egocentric, according to Lazare, who offers the former "apology." This attempt is destined to fail because it is offered not to make amends for an injury inflicted, but rather because the offender regrets "that he is no longer liked by the person he offended." 29

22. Aaron Lazare, Go Ahead Say You're Sorny, PSYCHOL TODAY, Jan.-Feb. 1995, at 40, 40.

23. See id.

24. Id. at 76 (quoting President Nixon's resignation speech of August 8. 1974).

25. See id.

26. Id. (quoting Senator Packwood).

27. See id. at 78 .

28. Id.

29. Id Others object not only for the reason suggested by Lazare, but also because the first attempt shifts the blame for the hur to the offended party and, in this process, inflicts yet another offense. See SUSAN JACOBY, WILD JUSTICE: THE EVOLUTION OF REVENGE 347-48 (1983). 
Of course, as Lazare and others note, the greatest impediment to apology is a pervasive cultural attitude that views apology as a weakness, an emotional expression antithetical to traditional American values of autonomy and independence. ${ }^{30}$ Yet examining the process that leads to apology reveals that its performance is an act of courage, not an expression of weakness. Lazare teaches us the difficulty of mustering the psychological strength to perform apology. In a similar vein, Tavuchis observes that the offender must conquer fear and gather courage because the process can be "as painful and devastating as . . . any form of physical retribution." 31 In the call to apologize, then, the offender sets out on a course that is difficult, pain-filled, and potentially humiliating, yet also one of great courage and strength.

We can begin to see how apologies are more than discursive social acts and how they surpass simple social ritual. In recognizing what is entailed in an apology, we see the moral quality of the act. Apology is moral because it acknowledges the existence of right and wrong and confirms that a norm of right behavior has been broken. It is moral, too, because the person who apologizes also exposes himself to the consequences of his wrongful act. When we consider how difficult it is to apologize, the strength and courage that its performance requires, we see that apology is indeed a heavily freighted moral action, one moral in its very expression. That is, the performance of authentic apology is itself a moral act, regardless of its efficacy. Yet, once performed, an apology sets in motion a call to the offended, a call for forgiveness.

This suggests that apology is multidimensional in moral terms. It begins with moral movement on the part of the offender and opens the opportunity for moral response on the part of the offended. In short, apology does not exist in isolation; it is, rather, an intensely relational process that cannot be understood alone any more than a promise could be understood without

30. See Lazare, supra note 22 , at 78 ; Levi, supra note 3 , at 1183 . Others would suggest that this is not necessarily an American value, but rather an American male value. See Deborah Tannen, I'm Sorry, I Won't Apologize, N.Y. TIMES, July 21, 1996, $\$ 6$ (Magazine), at 34. Tannen suggests that being male is itself an impediment to apology. See id. Pulitzer Prize-winning journalist Rick Bragg shares this observation in his recent autobiography. There, he describes the last time he saw his father, a wreck of a man who had abandoned his sons and his wife to a life of total poverty:

He talked and talked and never said a word, at least not the words I wanted. He never said he was sorry. He never said he wished things had tumed out different. He never acted like he did anything wrong. Part of it, I know, was culture. Men did not talk about their feelings in his hard world. I did not expect, even for a second, that he would bare his soul. All I wanted was a simple acknowledgment that he was wrong, or at least too drunk to notice that he left his pretty wife and sons alone again and again, with no food, no money, no way to get any, short of begging . . . .

RICK BRAGG, ALL OVER BUT THE SHOUTIN' 12 (1997). For others, this kind of gender assignment remains only a stereotype and speaks to the importance of further study. See Levi, supra note 3 , at $1184-86$.

31. TAVUCHIS, supra note 10 , at 35 . 
reference to promisor and promisee. Apology becomes "the middle term in a moral syllogism," a process that begins with an inner urging to repent and ends with forgiveness as a moral option for the offended..$^{32}$ Apology is, then, the centerpiece in a moral dialectic between sorrow and forgiveness. ${ }^{33}$

\section{FORGIVENESS}

Forgiveness is a topic that cuts across academic lines. Indeed, it crosses cultures and continents, disciplines and dogmas. It has philosophical and religious roots, yet today it is a much discussed subject in anthropological, sociological, political, and psychological circles as well. ${ }^{3+}$ What one means by forgiveness is therefore dependent on a variety of influences such as one's social, political, cultural, or religious location. I do not intend here to engage deeply in an interdisciplinary conversation about what forgiveness is and is not. Defining forgiveness is not the purpose of this Essay. What is important is to consider how apology acquires value in the process of forgiveness. This discussion will reveal the moral possibilities an apology can inspire. Yet it will also show the danger that apology presents in a litigation context, especially for those who demand expressed contrition as a condition precedent to forgiveness.

For legal philosopher Jeffrie Murphy, forgiveness, like apology is a moral activity, part of a ritual in our moral lives. ${ }^{33}$ As a philosopher, Murphy insists on looking at the purpose of forgiveness and finds there a moral motivation for forgiving. ${ }^{36}$ For Murphy, that motivation is the overcoming of resentment. ${ }^{37}$ In tying forgiveness to resentment, he adopts the prevailing philosophical view that defines forgiveness as the overcoming of resentment but adds his own requirement that the act of forgiveness be done only on moral grounds. ${ }^{38}$

32. Id at 20 .

33. We could pause here and formulate a Kantian critique of this teleological perspective, which sees apology not as an end in itself, but rather as a means toward obtaining forgiveness. We could focus on the moral implications of an action taken in order to receive and ask questions that dissect the legitimacy of an apology performed with that intention. Such an analysis would find support in modern culture, especially in programs such as 12-sicp groups, which encourage the performance of apology without regard to potentially positive possibilities. While I leave this critique for another essay, I do address apologies deployed for utilitarian means. See infra Part III.

34. Indeed, it has been suggested that the topic has given rise to an emerging field of "forgiveness studies." Scott Heller, Emerging Field of Forgiveness Studies Explores How We Ler Go of Grudges, CHRON. HIGHER EDUC., July 17, 1998, at A18. Noting that this is not a phenomenon limited to the United States, Heller cites studies in Northern Ireland. Rwanda, and South Africa. See id. at A18.

35. See, e.g., Jeffrie G. Murphy, Forgiveness and Resentmen, in JEFFRIE G. MURPHY \& JEAN HAMPTON, FORGIVENESS AND MERCY 14, 28 (1988).

36. See id. at 24.

37. See Jean Hampton, Forgiveness, Resentment and Hatred, in MURPHY \& HAMPTON, supra note 35 , at 35, 36 (discussing Murphy's views).

38. See HABER, supra note 17, at 6; Murphy, supra note 35, at 24. 
Murphy sees meaning in resentment. Indeed, he finds it a valuable and important stance. He looks past negative attitudes that typically attach to that term and sees the positive attribute of resentment: that resentment as an attitude protects the critical value of self-respect. For Murphy, "a person who does not resent moral injuries done to him ... is almost necessarily ... lacking in self-respect." ${ }^{39}$ Still, Murphy's attachment to resentment does not lead him to take a stand against forgiveness; rather, he sees value in forgiveness but insists that it be granted for a morally considered reason. ${ }^{40}$

Murphy insists upon intentionality on the part of the offended party. He calls upon the actual and critical memory of those injured to recall the injury inflicted and then to make a conscious choice regarding forgiveness. His argument cuts against the kind of religious dialogue that insists on forgiveness as a virtue in and of itself regardless of the magnitude of the offense or a change in the attitude of the offender. Murphy would argue that it is hardly a virtue to forgive if in the process of so doing, the forgiver overlooks or denies his own moral rights. In fact, Murphy would consider forgiveness granted too quickly and without a moral reason to be a vice. ${ }^{41}$

In Murphy's schema, apology becomes critical to overcoming resentment, since apology is the spoken performance of the offender's state of repentance, and Murphy demands contrition as one condition of forgiveness. Through apology the offender says, "I no longer stand behind the wrongdoing," thus giving verbal expression to having had a "sincere change of heart." ${ }^{22}$ The sincere apology sets the stage in Murphy's scenario for forgiveness, since the expression of contrition provides a legitimate moral reason for the offended party to grant forgiveness. For Murphy, forgiveness without apology would not be a moral act. It would be, as Susan Jacoby states, "a state of mind-a condition that may be emotionally ... meaningful to the one who forgives but has no significance as a social bond." ${ }^{43}$ Jacoby pushes us to see what Murphy means. She argues that while it is possible to forgive in the absence of an apology, we should not "if our forgiveness is to be morally respectable." 44

What is helpful about Murphy's position is his recognition that apology plays a crucial role in the process of forgiveness, a process that he sees as

39. See Murphy, supra note 35 , at 16 .

40. Murphy's reference to Marx is one example of his concern with the premature expression of forgiveness. Murphy suggests that when Marx leveled his critique of religion as "opiate of the masses," he must have meant to "suggest that Christianity ha[d] encouraged the development of meek and forgiving dispositions that will tolerate oppression, and that will call that toleration virtue." Jeffrie G. Murphy, Introduction to MURPHY \& HAMPTON, supra note 35, at 1, 9. Here, Murphy offers a critique of an inappropriate expression of forgiveness, not a condemnation of the concept.

41. See Murphy, supra note 35, at 17-18.

42. Id. at 26 .

43. JACOBY, supra note 29 , at 347.

44. HABER, supra note 17 , at 98 (describing Jacoby's views). 
moral. By seeing apology as a legitimate reason to overcome resentment, Murphy identifies it as an important ingredient in the healing of a moral injury. This suggests that apology has precisely the value I had originally imagined: Its authentic expression has moral meaning for both the offender and the offended as a vehicle for restoring moral balance. Understood this way, apology facilitates healing and reconciliation as an essential ingredient in the process of forgiveness. ${ }^{45}$

The problem with Murphy's perspective is that it ties the offended person to the offender. If the offender fails to act in a way that would, for Murphy, legitimate forgiveness, then the offended party must hold on to an attitude of resentment to maintain a moral position. This suggests not only a static moral stance, but also a dangerous dependency, especially for litigants. ${ }^{46}$ If I believe that you must apologize in order to free me of resentment, and if I desire to overcome resentment, then your apology becomes much more valuable to me than to another whose freedom from resentment is not tied to your apology. ${ }^{47}$ In the former instance, your

45. For a discussion of my understanding of healing, see supra notes 6-9 and accompanying text.

46. It also suggests that Murphy is not considering the negative consequences of maintaining resentment. Psychologist Phillip McGraw notes that there are both physical and emotional costs to such a stance: "When you harbor hatred, anger, and resentment, your body's chemical balance is dramatically disrupted. Your 'fight-or-flight' responses stay aroused twenty-four hours a day. seven days a week. That means that hatred, anger, and resentment are absolutely incompatible with your peace, joy, and relaxation." PHLLIP C. MCGRAw. LIFE STRATEGIES: DOING WHAT WORKS, DOING WHAT MATTERS 201 (1999).

47. There are two points here. First, apology is potentially more valuable to those who share Murphy's perspective. While I acknowledge that an apology may have more value to this group. I believe apology has value even for those whose religious and philosophical location encourages forgiveness without regard to apology. In shor, I think apology is valuable in the process of forgiveness for all human beings, but I highlight its special value for those, like Murphy, who insist on apology as a condition precedent to forgiveness. My second point is to identify those who would argue against Murphy's view that apology is a condition precedent to forgiveness. In this category would be ethicists like Haber who see that "[t]he wrongdoer need not be involved in any way for forgiveness to occur." HABER, supra note 17, at 11 . From this perspective. forgiveness is a virtue that can occur unilaterally and internally. This view maintains moral power in the offended agent, and, consequently, the offended party's moral stance is not tied to that of the offender. The offended can choose to forgive whether or not the offender chooses to engage in the performative act of apology.

This is a process a client demonstrated for me several years ago when he chose not to sue a real estate agent who, although a longtime friend, had forged the client's signature on a contract and then forwarded the client's check to the title company in a desperate antempt to force a sale. The client was initially in an understandable state of indignation. We quickly stopped payment on the check and, with the title company's cooperation, voided the transaction. While the damage was minimal, the client remained resentful, the agent uncontrite. A year or so later my client heard the agent was dying in a local hospital. The client reflected on the agent's desperate act, a reflection that caused him to recall the agent's equally desperate financial situation. My client decided to forgive. He went to the hospital to talk with the agent. expressed his sorrow that the friendship had been lost, and expressed forgiveness. My client said there was a warm conversation, an expression of gratitude by the agent that my client had come, yet the agent did not apologize. The agent died the next morning.

Under Murphy's view, my client's claim that he had overeome his resentment would not be morally justified because there was no apology on which the overcoming of resentment could be 
apology becomes potentially marketable, an item to offer in a bargained-for exchange. In short, an otherwise moral process becomes ripe for subversion. Not surprisingly, the opportunity to commodify apology has been noticed and used by lawyers.

Radin observes that "[m]arket rhetoric is the discourse of commodification." 48 She notes that in systems dominated by market rhetoric, all human interactions are viewed as market trades and "we conceive of all things persons value as fungible objects (commodities)." 49 Through the pragmatic lens of market rhetoric, all harm to a victim is measurable in dollars: "[T] he harm is simply a cost to the victim." ${ }^{30}$ In this worldview everything becomes a part of the exchange process, and everything has a price. Yet, as I argue here, this worldview itself comes with a price, particularly when it is cast broadly into the realm of human relations. I borrow from Radin in using the rhetoric of the market in this Essay to highlight how apology is frequently commodified in the legal arena, where a moral process can become a market trade. ${ }^{51}$

\section{THE COMMODIFICATION OF APOLOGY}

A recent case illustrates my point. Carole Coe, a criminal defense lawyer in Missouri, was trying a protracted conspiracy case in federal district court. ${ }^{52}$ During the course of the trial, Coe was held in contempt four times, and on the fourth finding was ordered into custody. After she

based. Proponents of unilateral forgiveness would view my client's action as inherently moral because he chose not to harm himself by maintaining a negative spiritual and psychological state. and because he chose to embrace the humanity of the agent. By seeing the agent's brokenness, my client was able to forgive.

While helpful in offering insight into the experience of unilateral forgiveness, this illustration also suggests that forgiveness is better understood as a process than as a single cvent. My client's movement to forgiveness, while unilateral, occurred over a year-long period. It is also important to note that the damage my client suffered was minimal. Would unilateral forgiveness have been attained after catastrophic loss? If so, rather than occurring over a year, might the process have taken a lifetime? Questions such as these reflect my view that forgiveness is a complicated and difficult process regardless of whether one agrees with Murphy or embraces the idea of unilateral forgiveness I describe here. My lived experience suggests that, regardless of one's ethical location, apology can serve as a catalyst to forgiveness, even if only by abbreviating the temporal dimension my client's narrative suggests. This means that apology has potential value for anyone who embraces forgiveness as a desirable moral goal.

48. Margaret Jane Radin, On the Domain of Market Rhetoric, 15 HARV. J.L. \& PUB. POL'Y 711,711 (1992); see supra text accompanying notes 6-8.

49. Radin, supra note 48 , at 711 .

50. Id. at 724 .

51. Of course, it is not only in the legal arena that the moral dimension of apology is subverted. Children are frequently forced to apologize as a condition of receiving a benefit. Whenever an apology is forced or used as a part of a bargained-for exchange, its moral dimension is potentially disrupted. I use the word "potentially" because I recognize that repentance is not always noninstrumental. See infra note 100 and accompanying text.

52. See In re Coe, 903 S.W.2d 916 (Mo. 1995) (en banc). 
apologized, the district judge vacated the contempt decree. ${ }^{53}$ Coe was later charged with violations of the Missouri rules of professional conduct, and, finding her guilty of professional misconduct, the Missouri Supreme Court suspended her from practice for six months. ${ }^{54}$ Two members of the court filed opinions "that suggested that if [Coe] would issue a public apology, they would consider changing their votes to impose only a public reprimand." 55 Not surprisingly, Coe apologized. True to their word, the judges changed their votes and Coe was given only a public reprimand. ${ }^{36}$

Some members of the court observed that Coe's apology failed to meet the markers of authentic apology outlined in this Essay. One judge noted that Coe's apology was not prompted by remorse, but rather by the incentive offered by the court to reduce the penalty imposed: "Given that incentive, [Coe] apologized. Who wouldn't?" 57 The dissent found the majority's acceptance of Coe's "post-opinion apology" an affront to precedent, her insincerity compounding "the injury to the process." $\$ 8$ While they did not use Radin's words, these judges described the process of commodification, where everything has a price, where a moral process becomes a market trade. ${ }^{59}$ Coe helps us see how the moral dimension of apology is easily lost when it is injected into the legal arena, even when it occurs under the scrutiny of an en banc court. When apology occurs in civil mediation, it is even more prone to commodification, more likely to be subverted. This is because mediation occurs in private settings where the gesture of apology is encouraged, yet its moral dimension often remains unexplored. I turn now to the role of apology in mediation. I show how this moral process is easily subverted into a market trade when cast into this arena.

Mediation can be defined as "an alternative to adjudication in which a neutral third party who has no final decisionmaking authority intervenes in negotiations to assist resolution of conflict." 60 In a mediation setting, parties often have opportunities for interaction that extend beyond those kinds of communications typically encouraged at the courthouse. As one legal commentator noted,

53. See id. at 917. Here Coe illustrates the point the U.S. Supreme Court made when it noted that "modification of contempt penalties is common where the contemnor apologizes or presents matter in mitigation." Groppi v. Leslie, 404 U.S. 496, 506 n.11 (1972).

54. See Coe, 903 S.W.2d at 920 (Covington, J., dissenting).

55. Id at 919 (Robertson, J., concurring).

56. See id. at 918.

57. Id at 919 (Robertson, J., concurring).

58. Id. at 921 (Covington, J., dissenting).

59. The financial advantage seems self-evident. What lawyer wants to lose six months of practice?

60. Levi, supra note 3, at 1169. 
Mediation elicits consent by fostering discussions "of general moral and interpersonal obligations as well as legal obligations," which in turn "activate... [a] sense of responsibility" in the parties. Mediation's encouragement of forays into moral and emotional expression sets the stage for gestures like apology, which register with the apologizee as moral recompense. ${ }^{61}$

Yet this moral dimension of apology is frequently overlooked by those facilitating mediated negotiations.

In an essay entitled Alternative Dispute Resolution by Apology: Settlement by Saying "I'm Sorry," lawyer-mediators Marshall Tanick and Teresa Ayling argue in favor of apology. ${ }^{62}$ From their perspective, apology is "one of the most effective means of averting or solving legal disputes." ${ }^{63}$ They observe that "[p]arties may be reluctant to apologize prior to a final settlement of a case because of concerns that the apology may be used as an 'admission' in litigation." ${ }^{64}$ They suggest that to avoid this technicality the lawyer must make sure that the apology is "carefully crafted to avoid admission of wrongdoing." 65

Tanick and Ayling later suggest that a good mediator will flush out the desire for apology early in the proceedings so that the possibility of apology as a means of resolution can be addressed. After all, an apology "can be an important element that lubricates settlement discussions." ${ }^{66}$ After offering their insights on the timing and typologies of apologies, the authors conclude with a utilitarian argument in favor of apology: "Lawyers, litigants, and prospective litigants all should be aware, however, of the utility of contrition. Apologies should be part of the arsenal of resources brought to bear in addressing and resolving legal disputes." 67

In their presentation, Tanick and Ayling seem oblivious to the moral dimension of apology and are apparently unconcerned with the strategic deployment of this otherwise moral act. By suggesting that an apology be "crafted to avoid the admission of wrongdoing," they erase a central element of apology: the admission of wrongdoing. By focusing on efficacy rather than contrition, Tanick and Ayling distort the moral principle that

61. Id. at 1171 (citations omitted).

62. Tanick \& Ayling, supra note 3, at 22-23. I use the term lawyer-mediator to make two points: Tanick and Ayling are lawyers and mediators, and not all mediators are lawyers.

63. Id. at 22.

64. Id. "Admission" as used here is a technical term referring to evidentiary rules that allow a statement to be introduced into evidence if the statement conveys a message that would generally be considered to be contrary to one's best interests.

65. Id.

66. Id. at 23 .

67. Id. at 25 . 
energized apology in my earlier discussion. Instead of being perceived as a moral ritual, apology becomes a material entity, an "object of exchange." 63

In this exchange scenario, apology becomes part of a bargain that requires two interdependent parties. In this transaction, "[t]he injured party depends on the offender's taking responsibility for the offensive act, and the offender depends on the injured party for absolution" for the mediation to succeed. ${ }^{69}$ Success here is measured by settlement rather than by moral restoration. Cast in this way, the apology itself becomes an "exchangeable good." 70 The apology is seen to produce a "happy ending" because each party saves time and fees. ${ }^{71}$ From a purely formal standpoint, this exchange model, in which responsibility is traded for absolution, resembles Murphy's model in which resentment is traded for forgiveness. But they are not the same in material expression. Murphy is neither looking for the "happy ending" nor measuring the value of the interaction in economic terms.

Missing from the exchange model is "the moral climate or sensibility required for authentic and effective apologetic discourse." 2 From a moral perspective, the bargained-for apology-the strategic object suggested by Tanick and Ayling-is not an authentic apology. This is because authentic "apology cannot come about and do its work under conditions where the primary function of speech is defensive or purely instrumental and where legalities take precedence over moral imperatives." 73 Does this mean that authentic apology cannot take place in a legal arena? Is an apology offered in the course of litigation always irrevocably tainted, like the apology before the Missouri court in Coe? Does the law itself contribute to the corruption of apologetic discourse?

Certainly, evidentiary rules that authorize the admission of apologies as a declaration against interest can have a chilling effect on the expression of contrition. That is, fear of legal consequences can operate as an obstacle to apology. Yet the view that the threat of legal sanction impedes the expression of apology must be distinguished from the idea that these evidentiary rules are themselves the cause of the moral corruption of apology. In the next Part, I focus on this distinction. Then, in Part V, I argue in favor of traditional evidentiary rules construing apologies as admissions because such rules are important protectors of the moral dimension of apologetic discourse.

68. Levi, supra note 3, at 1176.

69. Id.

70. Id.

71. Id.

72. TAVuchIS, supra note 10 , at 62 .

73. Id 


\section{THE LAW VIEWED AS AN IMPEDIMENT}

From Tanick and Ayling's perspective, the law itself becomes another impediment to be overcome in apologetic discourse, particularly evidentiary rules that allow an apology to be construed as an admission for consideration by a court or jury in a suit by the offended against the offender. From their vantage point, this evidentiary rule is a hurdle to be overcome just as were the cultural blocks addressed earlier in this Essay. ${ }^{74}$ Tanick and Ayling are not alone in taking this view, ${ }^{75}$ indeed, this perspective is received sympathetically in today's social and political climate. I argue, however, that when the legal evidentiary "impediment" of admission is removed, the moral dimension of apology is entirely eclipsed.

To understand how the law can itself be perceived as an impediment to moral discourse, one need only recall that, in the United States, law is founded on the "assumption of individual autonomy and choice, which implies that the individuals' interests are to be viewed in isolation and often in competition with those of others." 76 This competition is captured in a lawsuit, the purpose of which is to establish the fault of one party and offer relief to the other. This is hardly an atmosphere that encourages expressions of remorse. ${ }^{77}$

As I have already shown, an offender who desires to perform apology authentically must unequivocally express sorrow and accept responsibility for the violation of a norm. When these requirements are transposed from a social setting to the legal arena, they are magnified. The fear of admitting to wrongdoing is intensified when it is made within the litigation culture that pervades our society. Today, disputes that were once settled privately move into the public sphere in a way that "shifts the parties' focus away from private moral concerns to strategic maneuvers and legal consequences." 78 There is a tendency in this movement to place greater weight on winning than on moral healing, a trend sympathetically embraced by today's culture. It is a tendency that we in the United States have witnessed with increasing and disturbing frequency.

President Clinton's conduct in the Lewinsky scandal well illustrates this tendency. Even as he admitted that he had "sinned," he instructed his lawyers to take whatever steps were necessary to mount an effective defense. He has been criticized for what appears to be an inconsistent position, yet it is a position that some argue is demanded in a litigious

74. See supra notes 30-31 and accompanying text.

75. See, e.g., Cohen, supra note 3, at 1028-30; Orenstein, supra note 3, at 229-36; see also infra note 94 (examining Cohen and Orenstein's support for such evidentiary rules).

76. Wagatsuma \& Rosett, supra note 3 , at 495 .

77. See Levi, supra note 3, at 1188.

78. Id. 
culture. From this perspective, he is seen sympathetically, caught in a systemic vise "between the powers and liabilities of apologies." 79 From this perspective, it is understood that he could not be expected to have been more forthcoming, because "being more apologetic would have further weakened his position, given our 'argument culture': the current combative climate that values aggression more highly than conciliation." 80

Because of the demands of the law, this argument goes, we are to feel sorry for Clinton who is now no longer cast as offender but as offended by a system that first demands contrition and then authorizes use of the expression of this contrition against him. We are to believe that it is the system that interrupts another's moral inclination, that interferes with one's heartfelt desire to express sorrow and accept wrongdoing. Certainly this is the view of Tanick and Ayling when they suggest that apologies during mediated proceedings "should be carefully crafted to avoid admission of wrongdoing." ${ }^{81}$ This view, which perceives the interruption of apologetic discourse to be the product of a flawed system, has prompted legislators in at least two states to grapple with the issue by creating "safe harbors" for the expression of sympathy.

In the 1970s a Massachusetts legislator's daughter was killed while riding her bicycle. The driver who struck her never apologized. Her father, a state senator, was angry that the driver had not expressed contrition. He was told that the driver dared not risk apologizing, because it could have constituted an admission in the litigation surrounding the girl's death. Upon his retirement, the senator and his successor presented the legislature with a bill designed to create a "safe harbor" for would-be apologizors. ${ }^{82}$ This statute as enacted provides, in part:

Statements, writings or benevolent gestures expressing sympathy or a general sense of benevolence relating to the pain, suffering or death of a person involved in an accident and made to such person or to the family of such person shall be inadmissible as evidence of an admission of liability in a civil action. ${ }^{83}$

79. Deborah Tannen, About Last Week... Apologies: What It Means To Say "Sorry," WASH. POST, Aug. 23, 1998, at C1.

80. Id at $\mathrm{Cl}$.

81. Tanick \& Ayling, supra note 3 , at 22 .

82. The legislative history of this bill reveals little substantive information. The bill was sponsored by State Senator Robert C. Buell and former Senator William L. Saltonstall. In a phone interview with former Senator Buell, I leamed that he was asked by former Senator Saltonstall to sponsor the bill for the reasons outlined in the text. Telephone Interview with Senator Robert $C$. Buell (Apr. 25, 1999). Senator Buell did not recall any debate about the moral implications of a protected apology, and research of the legislative history and media reveals none.

83. MASS. GEN. LAwS ANN. ch. 233, § 23D (West Supp. 1998). 
The statute defines "benevolent gestures" as "actions which convey a sense of compassion or commiseration emanating from humane impulses." ${ }^{84}$ The Massachusetts statute became the model for a similar statute recently enacted in Texas, ${ }^{85}$ which the Austin American-Statesman dubbed the "I'm sorry" bill. ${ }^{86}$ Some view statutes such as these as a movement in the right direction, an important step toward the removal of systemic impediments to apology.

Included in this group are lawyer-mediators Peter Rehm and Denise Beatty, who applaud the Massachusetts law because "it provides a safe harbor for expressing sympathy for accidental injuries." ${ }^{87}$ So, for example, "when something bad happens in a health care context," health care providers can express sympathy for their part in causing "something bad" without worrying that their words can be used against them. ${ }^{88}$ According to Rehm and Beatty, this "serves the public interest because such expressions have the potential to reduce the number of lawsuits, rather than attract litigation." ${ }^{89}$ From their perspective, this provides "hope that with an increased understanding about the legal consequences of apology, more people will feel safe in tendering an apology." 90

There is, of course, a distinction between an apology as described in this Essay and the protected expressions of sympathy contemplated by the Massachusetts and Texas legislatures. Both statutes protect generic words that express sorrow about another human being's suffering. Neither protects an authentic apology, understood here as an expression of sorrow coupled with an unequivocal statement of wrongdoing. "What is protected are expressions like "I'm sorry you are suffering" or "I'm sorry for your loss." What is not protected are statements like "I'm sorry you are suffering because of my behavior. My conduct was wrong. I regret it, and the pain it has inflicted." The kinds of expressions protected by statutes such as these are more akin to botched apologies, apologies that fail precisely because of their generality. ${ }^{92}$ While sympathetic expressions may be useful in a fender bender, they are more likely to exacerbate pain in situations of catastrophic loss. Consider the widow who was enraged that none of the doctors

\section{Id.}

85. See TEX. CIV. PRAC. \& REM. CODE ANN. § 18.061 (West 1999).

86. See Sorry's Safe Now, AUSTIN AM.-STATESMAN, July 2, 1999, at A14.

87. Rehm \& Beatty, supra note 2, at 129.

88. Id.

89. $I d$.

90. Id. at 130 .

91. In fact, the Texas statute is explicit in this regard:

Notwithstanding the provisions of Subsections (a) and (b), a communication, including an excited utterance as defined by Rule 803(2) of the Texas Rules of Evidence, which also includes a statement or statements concerning negligence or culpable conduct pertaining to an accident or event, is admissible to prove liability of the communicator.

TEX. CIV. PRAC. \& REM. CODE ANN. \$18.061 (West 1999).

92. See supra notes $22-29$ and accompanying text. 
apologized for his part in causing her husband's death. If you were she, how would you respond if the negligent doctor said only, "I'm sorry you are suffering"? Would an expression of sympathy devoid of accountability help you heal? Would the protected words restore moral balance between you and the doctor?

It is understandable why legislators would attempt to craft vehicles by which human relations could be restored, especially since the system itself is seen as an impediment to the healing possibility of apology. After all, viewed casually, any step toward the restoration of human relations seems worthy. Yet these legislative efforts lack any serious reflection on the moral dimensions of apologetic discourse. ${ }^{93}$ This oversight has led to the confusion demonstrated here between authentic apology and the expression of sympathy. Yet this confusion is not the only harm caused when legislators fail to consider the moral aspect of apology. When the moral element of apology is overlooked, statutes like those in Massachusetts and Texas are viewed favorably because they construct "safe" space for the performance of apology. But those who favor the creation of "safe harbors" miss the mark. "In joining the growing chorus who want to blame

93. Recall that the Texas statute authorizes the admissibility of communications conceming negligence or culpable conduct. See supra note 91 . One might therefore conclude that the Texas legislature considered the moral implications of a protected apology. I interviewed John Fleming. who had suggested the bill to its sponsor, Representative Patricia Gray. Fleming explained that he had suggested the bill to Representative Gray after learning of the Massachusetts statute. He also explained that the provision contained in subsection (c) had been added in response to objections from the plaintiffs' trial association, Texas Trial Lawyers Association, an objection tied to trial advantage and not moral considerations. He acknowledged that the moral issues posed here had not been considered. Telephone Interview with John Fleming (Sept. 2, 1999).

94. Orenstein, for example, argues for a rule modification even more expansive than that provided by either the Massachusetts or Texas statutes. She proposes an absolute exception to those evidentiary rules that would admit apology into evidence so that "[a]ny statement of selfblame and contrition would be inadmissible, as would be the surrounding facts." Orenstein. supra, note 3, at 247. Under this plan, expressions of contrition or acknowledgments of blame could never "in themselves be admitted as evidence of negligence or wrongdoing." Id. at 248. Orenstein's proposal would supplant existing evidentiary rules that she likens 10 "the law of the sandbox": "Ha, ha, you said it, now you're stuck with your own admission." ld. at 249. According to her, "[T] hough it might be maddening for a defendant ... to deny in court what it admitted in an apology, the plaintiff on balance is better off . .." Id. at 255. Maddening? The plaintiff in the scenario Orenstein describes is actually in a worse position because of the protection Orenstein's proposal would extend. Now, instead of suffering only from the original injury, the plaintiff must suffer exacerbation of that injury by being forced to prove fault in spite of the defendant's admission. This exacerbation arises not only from the additional expense required to show fault but also from the additional moral indignation the plaintiff must suffer because of Orenstein's evidentiary exception.

Cohen agrees with Orenstein that "the law ought to be changed to foster apology." Jonathan R. Cohen, Nagging Problem: Advising the Client Who Wants To Apologize, DISP. RESOL. MAG. Spring 1999, at 19. Indeed, he feels that a "goal of the law in this area should be to permit an offender to make a full and 'safe' apology immediately after the injury or at any time thereafter, should he so choose." Cohen, supra note 3, at 1061 . Cohen states that a strength of such a "safe" apology is that it gives "the injured party maximal psychological satisfaction at the minimal legal exposure to the offender." Id. at 1051 n.139. He argues that the "safe" apology uncouples the issue of apology from the issue of liability. Id. at 1067. Cohen believes that this uncoupling is 
the system, they fail to see that what they consider systemic impediments to the performance of apology are actually safeguards of the moral integrity of the act.

\section{THE LAW AS GUARDIAN OF THE MORAL INTEGRITY OF APOLOGY}

Apologetic discourse is dyadic, a moral exchange between the primordial social categories of offender and offended. For an apology to be authentic, it must meet essential criteria: There must be an unequivocal expression of sorrow and an admission of wrongdoing. Without a meaningful and unequivocal expression of wrongdoing, apology cannot be an authentic moral act. Murphy relies on this authenticity to provide the moral reason to forgive. Recall, too, that the expression "I'm sorry" implies a willingness on the part of the performer to accept the consequences of the wrongful act. It is against this background that questions arise: Are apologies expressed in the safe harbors constructed by the Massachusetts and Texas legislatures, and endorsed by commentators, authentic? Can a protected apology provide a moral reason to overcome resentment, and thus allow the offended to forgive the offender? For insight into these questions, I bring my own lived experience, which supports the intellectual conversion that I underwent in writing this Essay.

Four years ago, my life partner was traveling within the designated speed limit on a residential street near our home in Dallas, Texas. An eighty-three-year-old woman failed to stop at a stop sign. She broadsided his car. In what was later described by witnesses as a spectacular crash, his jeep rolled over three times, its roof crushed. My partner suffered multiple injuries, the most serious of which were fractures to his back and a closedhead injury. Compounding the tragedy was the fact that the elderly woman maintained minimal automobile insurance, barely adequate to cover my

beneficial because it helps avoid much needless conflict and the adding of insult to injury. It is clear how this is beneficial to the offender. After all, the offender has an opportunity to unburden himself with "minimal legal exposure." Yet, like Orenstein, Cohen fails to appreciate how a "safe" apology potentially exacerbates the plaintiff's injury, how a safe apology can occur at the offended's expense. If the offender is truly contrite, why not admit liability and allow the case to proceed on damages alone?

Trials can be bifurcated so that liability can be considered separately from damages. This means that the admission of wrongdoing can be made while the offender maintains the opportunity to dispute differing perceptions of the consequences of the wrongful act. Some might argue that conceding liability while contesting damages is the equivalent of a botched apology. I disagree. A botched apology overlooks fault; it refuses to accept responsibility. In an admission of liability, the offender accepts fault and responsibility for the wrongful act. By separating liability issues from those regarding damages, the offender says only that he disagrees with the quantitative assessment of the harm caused. In accepting liability, the wrongdoer is "owning up" to the fact that harm has been caused by a moral transgression, and by trying damages, he asks help from outsiders in evaluating the cost of that harm. Considered in this way, the " maddening" effect described by Orenstein is avoided, and the potential for healing for both parties is attained. 
partner's first few days in intensive care. We discovered, however, that she owned a home that was worth more than a half-million dollars and that was unencumbered by a mortgage. She was a widow with no children and shared this home with a nephew. With the help of our lawyer, we developed a strategy.

We asked that she pay all of my partner's medical bills, lost wages, and future related medical expenses. We were willing to forgo other legal damages so that we could recoup our out-of-pocket expenses. To accomplish this, we asked that she place her home in a trust that would allow her to remain in it for as long as she lived, but would require that the house be sold upon her death, and a portion of the proceeds used to discharge her financial obligation to my partner. She refused. What she did instead was file an application for bankruptcy, a legal maneuver by which she sought to discharge any potential liability to my partner while protecting her home from any claim he might make. Our lawyer filed objections to this action and, at a later hearing, established that she had been less than candid in her application. After this hearing, she filed a voluntary motion to dismiss the bankruptcy. ${ }^{95}$

It was while I witnessed the bankruptcy proceeding and listened to her testimony that I first became aware of my resentment toward her. ${ }^{96}$ I realized that I did not resent her for failing to stop. I resented her for her unwillingness to accept responsibility for her wrong, and for compounding the wrong with lies and legal shenanigans. I wonder now, with the voices of Tavuchis and Murphy playing in my mind, if she had offered an apology during mediation, and if the apology had been protected as authorized by the Massachusetts or Texas legislatures, as suggested by Rehm and Beatty or by Tanick and Ayling, would I have accepted it?? Would an apology rendered in this context provide a sufficient moral reason to overcome resentment $?^{98}$ Should I have allowed such an apology to overcome my resentment? ${ }^{99}$

95. See In re Cleveland, No. 395-30342-RCM-7 (Bankr. N.D. Tex. May 18, 1995).

96. I am intentionally addressing my own feelings here and choosing to talk about how this incident affected me. I am not speaking for my partner.

97. This question is, of course, hypothetical. It assumes that the law would grant me legal rights in my partner's cause of action, such as the right of consorium granted to the nonphysically injured spouse in a heterosexual marriage. No state allows this kind of recovery to members of same-sex partnerships.

98. I ask the question in this way in order to recall the moral requirements insisted on by philosophers like Murphy, and also to recall the discussion of unilateral forgiveness, where forgiveness is imagined without regard to the expressed contrition of the offender. See supra note 47.

99. It is imperative that the reader understand that I speak only of $m y$ resentment, since I have no moral right to exercise vicarious forgiveness. This is a point made clear by both Tavuchis and Murphy, but perhaps most poignantly by Dostoevsky. In a vignette from The Grand Inquisitor. Ivan recalls the story of an eight-year-old "serf boy" who threw a stone and injured a dog that was a favorite of the general who ruled the land. As punishment, the general had the boy 
It is here, where theory meets praxis, that the teachings of Tavuchis and Murphy speak most loudly. If apology is to be authentic, the offender must clearly admit his wrongdoing; he must truly repent if the apology is to be considered a moral act. When an offender says, "I'm sorry," he must be willing to accept all of the consequences-legal and otherwise-that flow from his violation. If a person is truly repentant, he will not seek to distance himself from the consequences that attach to his action; rather, he will accept them as a part of the performance of a moral act and the authentic expression of contrition.

If the apology is made at the insistence of a mediator or encouraged by a lawyer as a strategic choice during a mediated proceeding, the moral process is potentially corrupted, the moral dialectic challenged. ${ }^{100}$ At the very least, it is proper to question the legitimacy of an apology in such a context. Such an apology occurs in an environment that values and encourages bargained-for exchange, and such an apology may be prompted more by a desire to expedite settlement than to respond to a call to repent. When the apology is shrouded with legal protection, when it cannot be considered an admission, when no legal consequence can attach to the party through the apology, apologetic discourse moves from potential to actual corruption. The moral process of apology in such a protected environment is now subverted.

This protected apology is the kind that causes me to shudder. It becomes "merely a pawn or gambit in a power game," full of words but devoid of meaning. ${ }^{101}$ This is the kind of apology that should be rejected

\footnotetext{
"stripped naked" and then forced him to run. See FYOdOR DOSTOEvSKY, THE BROTHIERS KARAMAZOV 243 (Richard Pevear \& Larissa Volokhonsky trans., Alfred A. Knopf 1990) (1880). The hounds caught him and tore him to pieces before his mother's eyes. Ivan suggests that there should be no forgiveness, at least no vicarious forgiveness, by the mother on behalf of her dead child: "Let her forgive him for herself, if she wants to, let her forgive the tormentor her immeasurable maternal suffering; but she has no right to forgive the suffering of her child who was torn to pieces...." Id. at 245.

100. It is important that the reader note the phrase "potentially corrupted." I use this phrase to hold open the idea that an apology can be prompted by a lawyer or mediator and retain moral integrity. A call to repent does not have to be purely noninstrumental and uninfluenced by anyone outside of the offender; that is, the call for repentance may arise externally, lead to apology, and the apology maintain its moral integrity. In fact, learning to hear the call to repent and to respond to that call is a part of a maturation process, one that requires attention and care, like the process by which human beings leam to share and consider others. This means that lawyers and mediators have the opportunity to contribute, by influence and example, to an essential humanizing process. A mediator friend told me of an occurrence that beautifully illustrates this point. He was mediating a case that involved the wrongful death of a teenage child. The mediation was stalled. The child's father said he wanted to talk with the corporation president in a room with only him, the president, and the mediator present. This was laboriously arranged. In that session, the father explained why he thought the president and the company were responsible for his child's death, how through a father's eyes it appeared to him that his child had been murdered. The corpornte president listened, then acknowledged that he himself had a teenager and, with tears of shame and remorse, apologized. After that meeting, the parties were able to resolve the case.
}

101. TAVUCHIS, supra note 10 , at 62 . 
and discouraged. This is not the time for an offended party to accept such an "apology"; rather, it is the time for the offended or the offended's lawyer to maintain focus on the offender's actions, not his words. This is a time to hold on to one's self-respect, not a time to trade resentment for air.

What becomes apparent from this argument is that it is not the law that corrupts the moral dimension of apology; it is the disregard of the law's reason. The law recognizes that an apology, when authentically and freely made, is an admission; it is an unequivocal statement of wrongdoing. The law permits such an acknowledgment to enter the legal process as a way to allow the performer of apology to experience the full consequences of the wrongful act. An apology made in this context, with full knowledge of the legal ramifications, is much more freighted than an apology made in a purely social context. Now the offender must confront not only shame, fear, and humiliation, but financial risk as well. This calls on the offender to exercise great courage, one of the markers of a truly moral act.

When lawyers, legislators, judges, and mediators disrupt this process by viewing apology in utilitarian terms, they subvert the moral potential of apology in the legal arena. When the performer of apology is protected from the consequences of the performance through carefully crafted statements and legislative directives, the moral thrust of apology is lost. The potential for meaningful healing through apologetic discourse is lost when the moral component of the syllogistic process in which apology is situated is erased for strategic reasons. ${ }^{102}$ This is why I write: to remind all of those involved in mediation that apology is a moral process, that moral meaning attaches to the purpose for which the performative utterance of apology is employed.

\section{CONCLUSION}

I am a proponent of apologetic discourse. Indeed, I have experienced and witnessed the healing mysteries of this sacred process many times in my life. I use "sacred" here to call attention to the fact that, from my perspective, apology and the moral process outlined in this Essay are embraced by the meanings that word suggests. I like that the breadth of "sacred" invites the reader to consider both religious and secular connotations implied in a term that, for some, may mean holy in a religious sense, and, for others, may mean inviolate, as in inviolate notions of

102. I refer only to the healing opportunities of apologetic discourse. As stated carlicr, I believe that the offended can forgive unilaterally, and thereby heal without regard to the actions of the offending party. That is, I believe that forgiveness effected unilatcrally can restore moral balance. See supra note 47. 
justice. ${ }^{103} \mathrm{I}$ believe it is important for those who enter into apologetic discourse to recall that they have entered into a sacred space.

Of equal importance is that all those who participate in the mediation process remember that the sacred space entered is of and between offender and offended. This idea reminds us that "the exclusive, ultimate, and ineluctable focus" in apologetic discourse is on the interaction between the offender and the offended. ${ }^{104}$ This suggests that those who seek to facilitate this interaction must be knowledgeable about the particular philosophical and psychological attitudes of the offender and the offended. ${ }^{105}$ To overlook these components is to set the stage for the failure of justice.

Consider, for example, the offended party who maintains Murphy's point of view, that the overcoming of resentment is tied to the offender's expression of remorse. If the offended party also believes his healing is dependent on the offender's contrition, and if the offended places a high value on healing, he may be susceptible to precisely the kind of manipulation proposed by Tanick and Ayling. This is the kind of client who might settle in the face of a strategic apology, only later to realize that he has been victimized again. ${ }^{106}$

When I was practicing law, I naïvely thought that apology was the missing link for my clients, the critical piece necessary for healing. I think differently now after learning how susceptible apologetic discourse is to corruption. Still, an apology can be made in a morally meaningful manner in a mediated environment, in a way that can offer healing for both the offender and the offended. For instance, an apology made by an offender

103. See 14 OXFORD ENGLISH DiCTIONARY $338-39$ (2d ed. 1989) (defining "sacred" as either holy in a religious sense or inviolate); see also WEBSTER's NEW WORLD COLLEGE DICTIONARY 1180 (3d ed. 1996) (same).

104. See supra note 14 and accompanying text.

105. As suggested earlier, other cultural constructions, like gender, should be considered. I would also suggest considering religious attitudes as they affect the moral process outlined in this Essay. Judaism, Christianity, Islam, Buddhism, and Hinduism each have particular theological perspectives regarding forgiveness, points of view that are relevant to this discussion. See Ann Kathleen Bradley, Seeking Forgiveness in the World's Spiritual Traditions, SPIRITUALITY \& HEALTH, Winter 1999, at 29. In Judaism, for example, forgiveness is not automatic, but must be earned through the process of $t$ 'shuvah (literally "return"), which requires contrition on the part of the offender. See id. Forgiveness is central to the Christian message and is to be unconditionally granted. See id. at 29-32. In Islam, as in Judaism, forgiveness is balanced with justice. See id. at 32-34. Buddhism views forgiveness as a natural result of the realization that we are all connected, that forgiveness of another is actually forgiveness of ourselves, that what one is doing to us is something we might have done to another over many lifetimes. See id. at 34-35. This last idea resonates with concepts of forgiveness in Hinduism, where the idea is that forgiveness interrupts negative cycles captured in concepts of karma. See id. at 35. This brief summary suggests how a party's religious location might influence a mediation stance.

106. I am not arguing that a protected apology has no utility or that it can never benefit the offended. In fact, Senator Buell advised me that, in drafting the Massachusetts bill, Senator Saltonstall believed that just hearing the words "I'm sorry" could be soothing. See supra note 82. What I am suggesting is that it is important that the victim understand the significance of a protected apology before relinquishing important legal rights. This points to the lawyer's role. 
without protection from the legal ramifications that attach to the acknowledgment of wrongdoing would suggest the kind of authentic apology that could lead to forgiveness of the offender, the overcoming of resentment by the offended. Still, the morality of the performance of apology can only be interpreted within the particular setting in which it is rendered. From my perspective, this awareness points squarely to the importance of the lawyer's role in apologetic discourse.

Lawyers need to understand the process of apologetic discourse as developed in this Essay, particularly the moral dimensions that energize its authentic expression. Apology can, in fact, occur in mediation in a morally just way, but as I have said, the setting makes it ripe for subversion, and apologetic discourse is, therefore, context-dependent. The lawyer must know the markers of authentic apology, and must be prepared to help the client understand the nuances of apology as outlined here. This is important for the plaintiff's lawyer so that his client is not duped into trading his resentment for the defendant's gain. It is important, too, for the lawyer of the defendant. If the defendant is contrite and wishes to apologize, he must understand the legal consequences of expressed contrition. If the defendant chooses to apologize, a defense lawyer needs to understand the construction of apology in order to help the defendant avoid a failed apology and the additional tensions and blocks a failed apology creates. If the defendant is not contrite and does not feel that he has committed a wrong, a staged apology would be a moral wrong. ${ }^{107}$ Knowledge of apologetic discourse is important for the mediator as well, so that the mediator can suggest the appropriate role of apology and provide a formula by which apology can serve the kind of telos Tavuchis suggests. Knowledge of apologetic discourse can also help the mediator avoid encouraging a moral subterfuge by suggesting the utilitarian deployment of apology and, thus, avoid the kind of unreflective stance demonstrated by mediators like Tanick and Ayling. What this discussion highlights is that all of those involved in the mediation process need to be educated about the moral implications of

107. This was apparently President Clinton's position in the Paula Jones debacle. There, Jones alleged that Clinton had made inappropriate sexual advances in a hotel while he was Governor of Arkansas. Jones demanded an apology. Later, after the Lewinsky matter surfaced, Clinton paid $\$ 850,000$ to settle the matter with Jones but refused to apologizc. See Neil A. Lcwis. Clinton Settles Jones Lawsuit with a Check for \$850,000, N.Y. TMES. Jan. 13, 1999. at A14. If the President was indeed not contrite, this was an appropriate moral choice. Yet, in light of the progressive apology in the Lewinsky matter, it is difficult to assign moral value to the President's behavior. After all, Jones was unable to produce the kind of evidence that prompted the apology by Clinton to Lewinsky and the citizens of the United States. This allows room to wonder whether the President was actually not contrite or, perhaps, not caught by Jones in the vise created by Lewinsky's now famous blue dress. 
restorative actions like apology. This insight suggests an important role for law schools and, more particularly, law-school clinics. ${ }^{108}$

I close with the hope that I have convinced those who are engaged in mediation that apologetic discourse is an intensely moral discourse, yet subject to subversion when viewed as a commodity. I hope this Essay leads those who participate in the mediation process to consider carefully the purpose of apology. If it is not an authentic response by an offender to a call to repent, then those who participate in mediation ought not to subvert this moral ritual for strategic purposes. In those cases, all must be satisfied with resolution without reconciliation, and trust the offended party to find healing in another quarter.

I have shown that the law can accommodate authentic apology, and that this performative act can in fact be fostered in the context of civil mediation. Authentic apologetic discourse occurs in an environment where the participants respect apologetic discourse as a moral activity and resist subverting the discourse for strategic and instrumental purposes. What this suggests is that there are spaces in law where apologetic discourse can lead to the kind of healing I originally envisioned for my clients. Yet these spaces must be understood as interstices within a system that focuses on rights and duties rather than on restorative acts. After all, the law is a "blunt instrument," a tool better suited for telling people what to do and how to behave than how to care for each other. ${ }^{109}$ For this reason, a litigant's quest for healing must often extend beyond the law into disciplines more practiced in healing hearts and souls.

108. The idea that law schools should participate in their students' moral education is controversial. Clinical Professor Mary Jo Eyster thinks this is a crucial responsibility, especially in the realm of negotiation. See Mary Jo Eyster, Clinical Teaching. Ethical Negotiation and Moral Judgment, 75 NEB. L. REV. 752 (1996). But see Lee Modjeska, On Teaching Morality to Law Students, 41 J. LEGAL EDUC. 71, 71-73 (1991). Professor Modjeska takes the opposite position. holding that a law classroom is not the place for moral instruction. Modjeska's words reflect the public's worst perception of lawyers' morality when he states: "Would I represent the accused murderer, rapist, narcotics dealer? I would-and have. Would their ultimate guilt or innocence be relevant to me? It would not. Would I represent alleged members of organized crime? I would and have. Would their nefarious activities be relevant to me? They would not." $I d$. at 72 . Leaving no room for doubt as to his opinion regarding a lawyer's role in the moral arena, Modjeska concludes, "Although I would certainly counsel legality, I would not counsel righteousness. I would not advise them-nor therefore the student-to go and sin no more. Nor would my professional retainer encompass such a pastoral role." Id. Reflection on Modjeska's words leads us to see that the controversy is about which morality to teach rather than whether morality should be taught at all.

109. See Jeremiah Creedon, To Hell and Back: To Break the Cycle of Revenge Countries Must Look Beyond the Law, UTNE READER, Mar-Apr. 1999, at 56 (quoting the view of Harvard law professor Martha Minow). 